\title{
Groundwater depletion embedded in international food trade
}

\author{
Carole Dalin ${ }^{1}$, Yoshihide Wada ${ }^{2,3,4,5}$, Thomas Kastner ${ }^{6,7}$, Michael J. Puma ${ }^{2,3,8}$ \\ ${ }^{1}$ Institute for Sustainable Resources, University College London, \\ 14 Upper Woburn Place, London, WC1H 0NN, U.K. \\ ${ }^{2}$ Columbia University, Center for Climate Systems Research, 2880 Broadway, New York, NY 10025, USA \\ ${ }^{3}$ NASA Goddard Institute for Space Studies, 2880 Broadway, New York, NY 10025, USA \\ ${ }^{4}$ Department of Physical Geography, Utrecht University, \\ Heidelberglaan 2, 3584 CS Utrecht, The Netherlands \\ ${ }^{5}$ International Institute for Applied Systems Analysis, Schlossplatz 1, A-2361 Laxenburg, Austria \\ ${ }^{6}$ Institute of Social Ecology, Vienna, Alpen-Adria Universitaet Klagenfurt, \\ Wien, Graz, Schottenfeldgasse 29, Vienna 1070, Austria \\ ${ }^{7}$ Senckenberg Biodiversity and Climate Research Centre (BiK-F), \\ Senckenberganlage 25, 60325 Frankfurt am Main, Germany \\ ${ }^{8}$ Center for Climate and Life, Columbia University, 61 Route 9W Palisades, NY 10964 USA
}


Recent hydrological modelling ${ }^{1}$ and Earth observations ${ }^{2,3}$ have located and quantified alarming rates of groundwater depletion over the world. This is primarily due to water withdrawals for irrigation, ${ }^{1,2,4}$ but the connections with their main driver, global food consumption, have not yet been explored. Here we show that approximately eleven percent of non-renewable groundwater use for irrigation is embedded in food trade, of which two thirds are exported by Pakistan, the United States and India alone. We provide the first quantification of depleting groundwater embedded in the world's food trade by combining unique global, crop-specific estimates of non-renewable groundwater abstraction with international food trade data. A vast majority of the world's population lives in countries sourcing nearly all their staple crop imports from partners who deplete groundwater to produce these crops, highlighting risks for global food and water security. Groups of countries are found particularly exposed to these risks as they both produce and import food irrigated from rapidly depleting aquifers, such as the USA, Mexico, Iran and China. These results can help improve the sustainability of global food production and groundwater resources management by identifying priority regions and agricultural products at risk as well as the end-consumers of these products.

Excessive abstraction of groundwater for irrigation is leading to rapid depletion of aquifers in key food-producing regions around the world (e.g. north-western India, the North China Plain, the central USA and California ${ }^{3,5}$ ). This depletion of the largest liquid freshwater stock on Earth threatens the sustainability of food production, and water and food security, not only locally, ${ }^{3,5}$ but also globally via international food trade. Aquifer depletion can also induce significant environmental degradation, such as land subsidence and seawater intrusion. ${ }^{6,7}$ The globalised dimension of groundwater depletion is poorly understood to date because of the lack 
of research integrating crop water use, groundwater depletion and international food trade.

Studies of water resources embedded in food trade, ${ }^{8-11}$ or virtual water trade, have sometimes distinguished between blue water (surface water and groundwater) and green water (soil moisture) sources, which can provide additional information on the potential environmental impact of their use (e.g. ref. ${ }^{12,13}$ ). More recently, indicators of water scarcity have been introduced, ${ }^{14}$ which help evaluate the sustainability of global food supply. However, while the need to integrate recent evaluations of groundwater abstraction with virtual water trade and footprint techniques has been highlighted, ${ }^{15}$ groundwater use, in particular groundwater depletion for irrigation (GWD), has not been accounted for in global virtual water trade analyses.

Here, we aim to fill this crucial gap in the quantification of the water sustainability of global agriculture and food trade. To do so, we estimate, for the first time, the amount of GWD embedded in the world's food production and international food trade. GWD is defined as the volume of groundwater that is abstracted for irrigation use in excess of the natural recharge rate and irrigation return flow, ${ }^{5}$ accounting for environmental flow requirements, and thus corresponds to an unsustainable use of groundwater for crop production. We combine global crop production data $^{16}$ with crop-specific estimates of GWD (using the PCR-GLOBWB model ${ }^{1,5}$ ) for 26 crop classes in years 2000 and 2010 to obtain GWD intensities for each commodity-country pair (Methods equation 1). We then multiply bilateral trade flows ${ }^{16}$ of 360 crop commodities by the GWD intensity of this commodity in the country of export to obtain GWD volume embedded in trade (Methods equation 2). Importantly, we apply an origin-tracing algorithm ${ }^{17}$ to identify exports flows from intermediary countries and assign them to the original country of production (see Methods). We identify the countries and crops contributing to global GWD, highlight key exporters and end-consumers of these crops irrigated from overexploited aquifers, and point out associated risks for local and global food and water security.

Global GWD has increased by $22 \%$ in ten years, from $240 \mathrm{~km}^{3}$ in 2000 , when it sustained 
$20 \%$ of the world's irrigation, ${ }^{5}$ to $292 \mathrm{~km}^{3}$ in 2010 . Over this period, global GWD has increased mostly due to rises in India (23\%), China (102\%) and the USA (31\%, Fig. 2). The commodities analysed here (excluding non-traded ones) account for $241 \mathrm{~km}^{3}$ of GWD (83\% of the total) in 2010 . Most GWD is concentrated in a few regions that rely significantly on overexploited aquifers to grow crops, mainly the USA, Mexico, the Middle East and North African region, India, Pakistan and China (Fig. 1-2 and Table 1), including almost all the major breadbaskets and population centers of the planet. The crops leading to the most depletion globally in 2010, both because of their large production and high GWD intensity, are wheat (22\% of global GWD, or $65 \mathrm{~km}^{3} / y$ ), rice (17\%), sugar crops (7\%), cotton (7\%) and maize (5\%). India and Pakistan use the largest volumes of GWD (30\% and 11\% of global GWD, respectively, Fig. 1, Table 1). India has the largest GWD for wheat and rice (31.3 and $21.3 \mathrm{~km}^{3} / y$, respectively), and China and the USA dominate GWD for maize (4.7 and $3.0 \mathrm{~km}^{3} / y$, respectively).

We observe important differences in GWD intensity across regions and crop classes (SI Spreadsheet 1). On average (in countries with GWD), wheat, rice and maize are produced with 812, 199, and 72 liters of GWD per kilogram of crop, respectively. High extremes are found in Kuwait $\left(21,900 L / k g_{\text {wheat }}\right)$, Iran $\left(2,100 L / k g_{\text {rice }}\right)$ and Saudi Arabia $\left(790 L / k g_{\text {maize }}\right)$.

The countries irrigating crops from overexploited aquifers export it in various proportions (Table 1). India keeps most of its large GWD-based crop production for domestic use (only $4 \%$ of GWD exported), while the USA, Pakistan and Mexico export significant portions of their GWD-based crop production $(42 \%, 26 \%$ and $23 \%$, respectively, Table 1). The exports of Pakistan, the USA and India alone account for more than two thirds of all GWD embedded in food trade (Extended Data Table 3). Pakistan is the largest exporter, with 29\% of the global GWD trade volume, followed by the USA (27\%) and India (12\%, Fig. 3 and Table 1).

Globally, about $11 \%$ of GWD $\left(25 \mathrm{~km}^{3} / y\right)$ is embedded in international crop trade, while $18 \%$ of global crop production is traded internationally. This difference could be due to either 
crops with relatively smaller GWD intensity being more traded than others, or countries with relatively less GWD exporting more than other countries.

Individual crops contributing most to global GWD transfers are rice (29\%), followed by wheat $(12 \%)$, cotton $(11 \%)$, maize $(4 \%)$ and soybeans $(3 \%)$. Citrus crops and sugar crops account for 5\% of GWD transfers each. The majority of Pakistan's GWD exports are embedded in rice ( $82 \%$ ), mostly to Iran (about 14\%), Saudi Arabia, Bangladesh and Kenya. USA's exports to its three main partners (China, Mexico and Japan) are much more diverse than Pakistan's, with the dominant commodity being cotton ( $24 \%$ of GWD exports), followed by wheat (16\%), maize (10\%) and soybeans (9\%). Even though most of India's GWD is for domestic consumption, India is still the third largest GWD exporter (Table 1), primarily via rice (25\%) and cotton (24\%), mainly to China. While soybean exports from the USA to China, which have quickly grown due to feed demand in China, have been highlighted as water-efficient, ${ }^{11,19}$ we find that they still induce $65 \%$ of GWD for soybean in the USA. This highlights the importance of including water sustainability and not just water productivity in virtual water trade analysis.

The major importers of GWD via crops include China (9\% of global GWD trade), the USA, Iran, Mexico, Japan, Saudi Arabia, Canada, Bangladesh, the UK and Iraq (Fig. 3, Extended Data Table 3). The vast majority of China's GWD imports (about $47 \%$ cotton and $14 \%$ soybeans) originate from the USA and India. Japan also imports significant GWD from the USA (about $23 \%$ maize and $17 \%$ wheat).

When considering exports per capita, Israel and Moldova replace India and Turkey among the ten largest GWD exporters (Extended Data Fig. 2 and Table 4). Five countries in the Middle East are among the top ten importers of GWD per capita (40-150 $\mathrm{m}^{3} /$ capita/y, Extended Data Fig. 3 and Table 5), highlighting the important dependence of this region on non-renewable groundwater for food imports.

Countries exporting GWD-based food (e.g. the USA, Pakistan, Italy and Mexico) may 
benefit in terms of trade, but this may not be viable in the long term due to the unsustainable use of aquifers currently supporting these exports. Importers, while saving domestic water, may be exposed to sustainability risk in their food supply, and could have some responsibility in the environmental damage and reduced water availability of their trade partners. Importantly, some importers are also water scarce themselves, and may not be able to substitute imports with locally irrigated food. Along with supply-side adaptation, consumers of GWD-based products could also consider demand-side changes, e.g. reducing meat consumption or food waste. ${ }^{20,21}$

Five of the ten countries with the most GWD, the USA, Mexico, Iran, Saudi Arabia and China, are also top importers of GWD via food trade (Fig. 2, Table 1 and Extended Data Table 3). Importantly, these key countries import or export crops irrigated from the world's most stressed aquifer systems. The food production relying on these aquifers is particularly unsustainable as the extraction rates are 20 to 50 times higher than required for sustainable groundwater use. ${ }^{15}$ For example, Iran mainly imports rice form Pakistan irrigated from the Upper Ganges and Lower Indus aquifers (overexploited by factors of 54.2 and 18.4, respectively) and exports perennial crops irrigated from the Persian aquifer (overexploitation factor 19.7) to neighbouring Iraq. Similarly, the USA imports about 1.5 times as much GWD from Mexico (mainly via citrus and sugar crops) as it exports there (mainly via cotton and maize, Fig. 3). These regions are hotspots of water and food security risks related to GWD, as an exhaustion of these threatened aquifers would impact food supply both domestically and in their waterstressed trade partners. Furthermore, these risks are shared with many other countries via trade linkages. Indeed, we find that large parts of the world's population live in countries that source $90 \%$ or more of their staple crops imports from partners depleting groundwater to produce these crops: $89 \%$ of the population for sunflower, three quarters for maize, and a third for wheat and rice (Extended Data Table 6). Even though some countries with GWD only use it for a small part of their agricultural production, an exhaustion of currently overexploited aquifers repre- 
sents a considerable risk for the global food supply, as it could also affect imports of a majority of people.

Projections of food demand and water availability ${ }^{16,22}$ suggest that GWD will continue to increase in the absence of targeted measures. Pakistan's rice exports have more than quadrupled from 1990-2010 and draw about a quarter of the country's GWD in 2010. Increasing rice demand abroad has likely played a considerable role in depleting this country's aquifers, and accelerated depletion seems probable given projected population growth in both Pakistan (by $82 \%$ from 2010 to $2050^{23}$ ) and its importing partner countries (e.g. Kenya, Bangladesh and Iran, by $137 \%, 33 \%$ and $25 \%$, respectively ${ }^{23}$ ).

GWD exports of top exporters have significantly increased from 2000-2010 (2-fold in India, by $70 \%$ in Pakistan and $57 \%$ in the USA), and the largest increase in GWD imports (3 fold) occurred in China, mainly originating from the USA and India (Table 1, Fig. 2-3 and Extended Data Fig. 1). Projected population growth in China until 2030, and changing diets requiring soybeans for animal feed ${ }^{11}$ will likely further increase GWD for soybeans in the USA in the next decades. Surface water availability is expected to become more variable with climate change and the depletion of groundwater reserves will make it more difficult for agricultural regions to buffer these variations. Moreover, water availability is predicted to decline particularly in northern Pakistan and Iran, ${ }^{22}$ regions which already rely on non-renewable groundwater for irrigation.

We note that while we use state-of-the-art techniques for groundwater depletion estimates, which have been extensively validated (see Methods), further work is required to reduce the associated uncertainties. ${ }^{1}$ Besides, further modelling efforts are needed to project the exhaustion time of aquifers and establish trends based on future water supply and demand patterns.

Our results, identifying regions, crops and trade relationships most reliant on overexploited aquifers, can help target efforts to improve the sustainability of water use and food production. 
Solutions to minimize GWD could include, in the producing countries, water saving strategies ${ }^{24}$ such as improving irrigation efficiency and growing more drought resistant crops, together with targeted measures, such as metering and regulation of groundwater pumping. These policy efforts need to be further supported by local analysis considering socio-economic, cultural and environmental aspects. ${ }^{25}$ We also identify importing countries, which should support sustainable irrigation practices in their trade partners.

\section{References}

1. Wada, Y., Wisser, D., and Bierkens, M. Global modeling of withdrawal, allocation and consumptive use of surface water and groundwater resources. Earth Syst. Dynam. 5, 15-40 (2014).

2. Rodell, M., Velicogna, I., and Famiglietti, J. S. Satellite-based estimates of groundwater depletion in india. Nature 460, 999-1002 (2009).

3. Famiglietti, J. The global groundwater crisis. Nature Clim. Change 4(11), 945-948 (2014).

4. Scanlon, B. R., Faunt, C. C., Longuevergne, L., Reedy, R. C., Alley, W. M., McGuire, V. L., and McMahon, P. B. Groundwater depletion and sustainability of irrigation in the us high plains and central valley. Proc. Nat. Acad. Sci. 109(24), 9320-9325 (2012).

5. Wada, Y., van Beek, L., and Bierkens, M. Nonsustainable groundwater sustaining irrigation: a global assessment. Water Resour. Res. 48(W00L06) (2012).

6. Bouwer, H. Land subsidence and cracking due to ground-water depletion. Ground Water 15(5), 358-364 (1977).

7. Konikow, L. F. and Kendy, E. Groundwater depletion: A global problem. Hydrogeol. J. 13, $317-320$ (2005). 
8. Chapagain, A. K., Hoekstra, A., and Savenije, H. Water saving through international trade of agricultural products. Hydrol. Earth Sys. Sci. 10, 455-468 (2006).

9. Hanasaki, N., Inuzuka, T., Kanae, S., and Oki, T. An estimation of global virtual water flow and sources of water withdrawal for major crops and livestock products using a global hydrological model. J. Hydrol. 384(3-4), 232-244 (2010).

10. Konar, M., Dalin, C., Suweis, S., Hanasaki, N., Rinaldo, A., and Rodriguez-Iturbe, I. Water for food: The global virtual water trade network. Water Resour. Res. 47(5) (2011).

11. Dalin, C., Konar, M., Hanasaki, N., Rinaldo, A., and Rodriguez-Iturbe, I. Evolution of the global virtual water trade network. Proc. Nat. Acad. Sci. 109(16), 5989-5994 (2012).

12. Konar, M., Dalin, C., Hanasaki, N., Rinaldo, A., and Rodriguez-Iturbe, I. Temporal dynamics of blue and green virtual water trade networks. Water Resour. Res. 48(7) (2012).

13. Marston, L., Konar, M., Cai, X., and Troy, T. J. Virtual groundwater transfers from overexploited aquifers in the united states. Proc. Nat. Acad. Sci. 112(28), 8561-8566 (2015).

14. Mekonnen, M. M. and Hoekstra, A. Y. Four billion people facing severe water scarcity. Science Advances 2(2) (2016).

15. Gleeson, T., Wada, Y., Bierkens, M. F. P., and van Beek, L. P. H. Water balance of global aquifers revealed by groundwater footprint. Nature 488, 197-200 (2012).

16. FAO. Faostat online database. FAOSTAT Online Database (2015).

17. Kastner, T., Kastner, M., and Nonhebel, S. Tracing distant environmental impacts of agricultural products from a consumer perspective. Ecol. Econ. 70(6), 1032 - 1040 (2011). 
18. Dalin, C. and Conway, D. Water resources transfers through southern african food trade: water efficiency and climate signals. Environ. Res. Lett. 11(1), 015005 (2016).

19. Dalin, C., Hanasaki, N., Qiu, H., Mauzerall, D., and Rodriguez-Iturbe, I. Water resources transfers through chinese interprovincial and foreign food trade. Proc. Nat. Acad. Sci. 111(27), 9774-9779 (2014).

20. Jalava, M., Kummu, M., Porkka, M., Siebert, S., and Varis, O. Diet change a solution to reduce water use? Environ. Res. Lett. 9(7), 074016 (2014).

21. Vanham, D., Bouraoui, F., Leip, A., Grizzetti, and Bidoglio, G. Lost water and nitrogen resources due to eu consumer food waste. Environ. Res. Lett. 10(8), 084008 (2015).

22. Schewe, J., Heinke, J., Gerten, D., Haddeland, I., Arnell, N. W., and etal. Multimodel assessment of water scarcity under climate change. Proc. Nat. Acad. Sci. 111(9), 32453250 (2014).

23. WorldBank. World bank databank. http://databank.worldbank.org/data/home.aspx (2016).

24. Wada, Y., Gleeson, T., and Esnault, L. Wedge approach to water stress. Nature Geosci. 7(9), 615-617 (2014).

25. Aldaya, M. M., Martínez-Santos, P., and Llamas, M. R. Incorporating the water footprint and virtual water into policy: Reflections from the mancha occidental region, spain. Water Resources Management 24(5), 941-958 (2010).

26. Siebert, S. and Doll, P. Quantifying blue and green virtual water contents in global crop production as well as potential production losses without irrigation. J Hydrol 384, 198-217 (2010). 
27. Portmann, F., Siebert, S., and Doll, P. Mirca2000 global monthly irrigated and rainfed crop areas around the year 2000: A new high-resolution data set for agricultural and hydrological modeling. Global Biogeochem. Cycles 24(GB1011) (2010).

28. Wada, Y., van Beek, L., Weiland, F. C. S., Chao, B. F., Wu, Y.-H., and Bierkens, M. Past and future contribution of global groundwater depletion to sea-level rise. Geophys. Res. Lett. 39, L09402 (2012).

29. Rohwer, J., Gerten, D., and Lucht, W. Development of functional types of irrigation for improved global crop modelling. Number 104. Institute for Climate Impact Research, Potsdam, Germany, (2007).

30. Wada, Y., van Beek, L., and Bierkens, M. Modelling global water stress of the recent past: on the relative importance of trends in water demand and climate variability. Hydrol. Earth Syst. Sci 15, 3785-3808 (2011).

31. FAO. Technical Conversion Factors for Agricultural Commodities. FAO Rome, (Accessed January 2015).

32. Kastner, T., Karl-Heinz, E., and Haberl, H. Rapid growth in agricultural trade: effects on global area efficiency and the role of management. Environ. Res. Lett. 9, 034015 (2014).

Supplementary Information Supplementary Information is linked to the online version of the paper at www.nature.com/nature.

Acknowledgements C.D. acknowledges the funding support of the Belmont Forum (SAHEWS project, NERC NE/L008785/1), the Economic and Social Research Council through the Centre for Climate Change Economics and Policy, and the Natural Environment Research Council Fellowship (NERC NE/N01524X/1). T.K. is supported by the European Research 
Council Starting Grant LUISE (263522). M.J.P. acknowledges fellowship support from the Columbia University Center for Climate and Life. Y. W. is supported by Japan Society for the Promotion of Science (JSPS) Oversea Research Fellowship (grant no. JSPS-2014-878).

Author Contribution C.D., Y.W. and M.J.P. designed the research. Y.W. carried out the simulation to estimate non-renewable groundwater abstraction per crop class. T.K., M.J.P. and C.D. processed the trade data. C.D. performed the analysis. C.D. wrote the paper with help from Y.W., M.J.P. and T.K..

Author Information We declare no competing financial interest. Reprints and permissions information is available at www.nature.com/reprints. Correspondence and requests for materials should be addressed to c.dalin@ucl.ac.uk. 


\begin{tabular}{|c|c|c|c|c|c|c|c|c|}
\hline \multirow{13}{*}{$\begin{array}{c}\text { Year } \\
2010\end{array}$} & Rank & Name & $\operatorname{GWP}\left(\mathrm{km}^{3} / y\right)$ & $\%$ world & $\operatorname{GWI}\left(k m^{3} / y\right)$ & $\%$ natl GWcons & $\operatorname{GWE}\left(k m^{3} / y\right)$ & $\%$ natl GWP \\
\hline & 1 & India & 73.5 & 33.9 & 0.2 & 0.3 & 3 & 4 \\
\hline & 2 & Iran & 33.3 & 15.4 & 1.4 & 4.2 & 1.2 & 3.5 \\
\hline & 3 & Pakistan & 27.5 & 12.7 & 0.2 & 1.2 & 7.3 & 26.4 \\
\hline & 4 & China & 24 & 11.1 & 2.2 & 8.5 & 0.3 & 1.1 \\
\hline & 5 & USA & 16.2 & 7.5 & 1.7 & 15.3 & 6.9 & 42.4 \\
\hline & 6 & Saudi Arabia & 12.5 & 5.7 & 0.8 & 6 & 0.4 & 3.5 \\
\hline & 7 & Mexico & 11.1 & 5.1 & 1 & 10.6 & 2.5 & 22.6 \\
\hline & 8 & Libya & 2.5 & 1.1 & 0.1 & 2.4 & 0 & 0.1 \\
\hline & 9 & Turkey & 2 & 0.9 & 0.5 & 22.6 & 0.4 & 18 \\
\hline & 10 & Italy & 2 & 0.9 & 0.5 & 27.9 & 0.8 & 39.2 \\
\hline & & Total top 10 & 204.6 & 84.8 & 8.6 & 4.5 & 22.8 & 11.1 \\
\hline & & Total world & 241.4 & 100 & 25.6 & NA & 25.6 & NA \\
\hline \multirow[t]{12}{*}{2000} & 1 & India & 58.9 & 33 & 0.8 & 1.4 & 1.5 & 2.6 \\
\hline & 2 & Iran & 28.4 & 15.9 & 0.3 & 1.1 & 2.2 & 7.7 \\
\hline & 3 & Pakistan & 23.9 & 13.4 & 0.3 & 1.4 & 4.3 & 18.1 \\
\hline & 4 & Saudi Arabia & 13.6 & 7.6 & 0.5 & 3.3 & 0.3 & 2.1 \\
\hline & 5 & USA & 12.9 & 7.2 & 0.9 & 9.8 & 4.4 & 33.9 \\
\hline & 6 & China & 11.8 & 6.6 & 0.8 & 6.7 & 0.3 & 2.6 \\
\hline & 7 & Mexico & 11.4 & 6.4 & 0.9 & 8.2 & 1.6 & 14.2 \\
\hline & 8 & Libya & 2.7 & 1.5 & 0 & 1.3 & 0.1 & 2.5 \\
\hline & 9 & Turkey & 1.6 & 0.9 & 0.3 & 16.1 & 0.3 & 15.7 \\
\hline & 10 & Bulgaria & 1.5 & 0.8 & 0 & 1.1 & 0.3 & 18.7 \\
\hline & & Total top 10 & 166.7 & 85.6 & 4.8 & 3.1 & 15.3 & 9.2 \\
\hline & & Total world & 194.7 & 100 & 17.7 & NA & 17.7 & NA \\
\hline
\end{tabular}

Table 1: Groundwater depletion embedded in food balance for ten countries with most depletion for irrigation in years 2000 and 2010. Groundwater depletion in national food production (GWP), imports (GWI) and exports (GWE), and corresponding fractions of GWD in global food production (\% world), national food consumption (\% natl GWcons) and national food production (\% natl GWP), respectively. We also show totals for these 10 countries and for the world. 
Figure 1: Crop specific contribution to groundwater depletion worldwide in 2010. The pie charts show fractions of groundwater depletion for irrigation (GWD) of major crops by country, and their sizes indicate total GWD volume. The background map shows groundwater stress index (corresponding to overexploitation when larger than one) of major aquifers. ${ }^{15}$ Some countries have overexploited aquifers but no pie chart because groundwater use is not primarily related to irrigation. Underlined font indicates cases where pie charts are displaced for clarity.

Figure 2: Groundwater depletion associated with national crop production and consumption of major traders in (a) 2010 and (b) 2000. The top ten importers of GWD are shown in bold font and the top ten exporters of GWD are underlined.

Figure 3: Embedded groundwater depletion in international trade of crop commodities in 2010. Volumes in $\mathrm{km}^{3} / \mathrm{y}$. The top ten importers are shown in bold font and the top ten exporters are underlined. Ribbons' colors indicate the country of export. Note that, for clarity, we only display the links with a weight of at least $1 \%$ that of the largest link (i.e. the top $1.8 \%$ links which account for $81 \%$ of total flow and involve 71 countries). 


\section{Methods}

\section{Simulation of nonrenewable groundwater abstraction for crop water use}

Water used by irrigated crops is obtained from three sources: local precipitation contributing to soil moisture available for root water uptake (i.e. green water), irrigation water taken from rivers, lakes, reservoirs, wetlands and renewable groundwater, and irrigation water abstracted from nonrenewable groundwater. ${ }^{26}$

Here, we explicitly quantify globally the amount of nonrenewable groundwater abstraction to sustain current irrigation practice (GWD) separately for 26 crop types based on the MIRCA2000 dataset, ${ }^{27}$ for years 2000 and 2010. Irrigated cropland areas from MIRCA2000 are scaled to year 2010 based on national irrigated cropland areas annual data. ${ }^{16}$ We use a global hydrological and water resources model ${ }^{1,5}$ to simulate crop water use for the 26 irrigated crop types, and available blue and green water to meet this demand at a 0.5 degree spatial resolution, i.e. about $50 \mathrm{~km}$ at the equator. In order to distinguish nonrenewable groundwater abstraction from renewable water sources, we keep track of the amount of groundwater pumped for each irrigated crop on the basis of crop growing areas and seasons, including multicropping practices and considering sub-grid variability of different crop types. We subsequently compare this amount with simulated groundwater recharge to estimate nonrenewable groundwater that is withdrawn for separate crops. We then obtain country-level groundwater depletion $N R G W(i, K, n)$ (in $k g_{w a t e r}$ ) per crop class $K$ in each country $i$ and year $n$ by summing the gridded groundwater depletion per crop class over the grid cells within the country's boundaries. All model simulations by PCR-GLOBWB have been conducted at the 0.5 degree resolution, including groundwater depletion, groundwater recharge, and irrigation return flow. The results have then been aggregated to the country scale to match the trade data.

Note that groundwater recharge used in this calculation is based on a long-term average 
(1960-2010), ${ }^{5,28}$ which reduces potentially large inter-annual variability. Besides, natural groundwater recharge from precipitation is averaged over each grid cell, but return flow from irrigation is simulated for separate crop areas of each grid cell. For example, higher return flow occurs from the rice growing fraction of the grid cell compared to other crop growing fractions (e.g., wheat, maize) due to flooding irrigation practice. Irrigation return flow, i.e. percolation losses from irrigation water supply, is constrained by the reported country-specific loss factor based on ref, ${ }^{29}$ where different irrigation types (e.g., flooding irrigation, sprinkler, and drip) and the associated conveyance and management loss factors are considered.

We also note that the global model used to estimate groundwater depletion has been extensively validated in earlier work. For example, simulated river discharge, total water storage, total water withdrawal and total consumptive water use, and surface and groundwater withdrawal have been validated against GRDC discharge station data (more than 3000 stations), GRACE satellite observations, country statistics from FAO AQUASTAT, EUROSTAT, USGS, Indian, Chinese, and Mexican national government statistics, respectively. ${ }^{1,5,28,30}$ These comparisons show good agreement for river discharge and total water storage ( $R^{2}$ greater than 0.8$)$ for most of the catchments of the world. For water use, comparison with the reported value per country also shows a good agreement from 1970 to 2010 with $R^{2}$ being over 0.95 . Although the correlations are high for most countries, deviations are relatively large (more than 20\%) for several countries like Iraq, Lithuania, Puerto Rico, Mali, Djibouti and Bhutan. However, these countries have negligible groundwater depletion and the overall impact on GWD embedded in trade flows is thus very limited.

Estimated groundwater depletion has also been validated for over 30 regions and mostly compared well ( $R^{2}$ about 0.8$)$ with regional reported depletion values for areas including Northern India and Pakistan, North China Plains, High Plains Aquifer, Central Valley California, Arabian Peninsula, and Mexico. ${ }^{28}$ 


\section{Groundwater depletion embedded in traded crops}

Food Production and Trade Data We use detailed trade matrices data ${ }^{16}$ to calculate the trade of a commodity $c$, from a country $i$ to another country $j$ in year $n$ (2000 or 2010), noted $T(i, j, c, n)$. To smooth out annual variability in trade data, we use a three year average around each year of interest. We note that the portion of production not exported internationally may be traded within the country's boundaries, but this is not the focus of this study.

We first aggregate these trade matrices $T$ for 360 commodities $c$ (excluding those not present in trade data, mostly fodder crops, Extended Data Tables 1 and 2) into primary crop equivalent (pe) of 130 primary crops (listed in Extended Data Table 1), using the following conversion factor based on extraction rate from FAO commodity trees: ${ }^{31}(1 /$ rate $(c)) *$ $\left(\right.$ rate $(c) / \sum_{c^{\prime} \in \text { branch }} \operatorname{rate}\left(c^{\prime}\right)$. The first term is based on the definition of the FAO extraction rate, where rate $(c)$ is the FAO extraction rate for commodity $c$, and the second term avoids double counting a primary crop (e.g. raw wheat) if two by-products in the same branch (e.g. wheat bran and wheat flour) originated from this primary crop are traded. We also include estimates of feed crops embodied in traded animal products. ${ }^{32}$ The trade matrices obtained are noted $T_{p e}(i, j, c, n)$ : trade from country $i$ to $j$ of commodities derived from primary crop $c$ in year $n$, in primary crop equivalent.

Second, we correct trade flows by applying the origin-tracing algorithm developed in ref. ${ }^{17}$ This is an important preliminary stage to the multiplication of trade flows by the water coefficient in the country of origin. Some reported trade in the published FAOSTAT detailed trade matrices data ${ }^{16}$ can be re-exports (including after processing) of crops grown in a third country. This correction method aims to re-assign trade flows to the original country of production, addressing reported exports in excess of domestic production, based on production and trade data, ${ }^{16}$ so that the GWD intensity of the country of production is applied rather than that of an intermediary country. 
A potential source of uncertainty in the trade data relates to differences in reports by importers and exporters for the same trade link. For instance, country A reports a different import volume from country B than the export volume reported by country B to country A. This can have a number of actual reasons (e.g., shipments leaving and arriving in a different years or being rerouted while on sea) but can also be due to differences in reporting quality among nations. To test how this uncertainty affects the overall outcome of our study, we performed the calculations with two different trade data sets. In the first one, noted $i e$ (import-export), we use reported import data, with reported export data only used to fill data gaps. Assuming imports reporting is more reliable than exports reporting due to customs records at the port of entry, we present main results based on this version. In the alternative version, noted ei (export-import), we use the reported export data, with reported import data only used to fill data gaps. We find that the distributions of national GWD exports and imports obtained using ie trade data are very similar to those obtained with $e i$ trade data (Extended Data Figure 4). For top trading nations, we find that varying trade data has a relatively small effect on national GWD imports and exports: less than 15 percent variation (Extended Data Table 3), with exceptions of Bulgaria's exports (41\% or $\left.0.19 \mathrm{~km}^{3}\right)$ in 2010, Iran's exports in $2000\left(22 \%\right.$ or $\left.0.48 \mathrm{~km}^{3}\right)$ and India's imports in 2000 $\left(57 \%\right.$ or $\left.0.45 \mathrm{~km}^{3}\right)$.

GWD intensity and GWD in trade The groundwater depletion intensity (GWD per unit crop) of each crop class in each country and year is obtained as follows:

$$
G W C(i, K, n)=N R G W(i, K, n) / \sum_{c \in K} P(i, c, n)
$$

where $G W C(i, K, n)$ is the groundwater depletion intensity (or "content") of crops in class $K$, country $i$ and year $n$ (in $k g_{\text {water }} / k g_{\text {crop }}$ ); $P(i, c, n)$ is the production of raw commodity $c$ in country $i$ and year $n$ (in $k g_{\text {crop }}$ ), obtained from ref.; ${ }^{16}$ and $N R G W(i, K, n)$ is the non-renewable groundwater abstraction for irrigation (or GWD) of crops in class $K$, for country $i$ and year $n$ 
(in $k g_{\text {water }}$ ). We get the list of raw commodities (c) in each of the 26 MIRCA crop classes by using the MIRCA list $^{27}$ and selecting the crops with extraction rate equal to one. We then assume that, for country $i$ and year $n$, each commodity in a class $K$ (e.g. lemon and orange in the citrus class) has a GWC equal to $\mathrm{GWC}(\mathrm{i}, \mathrm{K}, \mathrm{n})$ and noted as $\mathrm{GWC}(\mathrm{i}, \mathrm{c}, \mathrm{n})$.

The variability in GWD intensities across countries with GWD may be explained by two major factors: the crop's water productivity and the mix of rainfall and irrigation water sources. For example, Pakistan and India have relatively similar water use for rice $(3,300$ and 2,900 $\mathrm{L} / \mathrm{kg}$, respectively ${ }^{18}$ ), but because India has more surface water resources, it uses eight times less GWD per unit rice than Pakistan (148 L/kg vs 1,280 L/kg, SI Spreadsheet 1).

Then we use this coefficient to convert trade flows into virtual water flows, as follows:

$$
G W T_{p e}(i, j, c, n)=G W C(i, K, n) * T_{p e}(i, j, c, n)
$$

where $G W T_{p e}(i, j, c, n)$ is the GWD embedded in trade from country $i$ to $j$ of commodities derived from primary crop $c$ in year $n\left(k g_{w a t e r}\right), T_{p e}(i, j, c, n)$ is the trade from country $i$ to $j$ of commodities derived from primary crop $c$ in primary crop equivalent $\left(k g_{\text {crop }}\right)$ in year $n$, and $K$ is the crop class to which primary crop $c$ belongs. Finally, we obtain the GWD embedded in trade per crop class with the following sum: $G W T_{p e}^{c l a s s}(i, j, K, n)=\sum_{c \in K} G W T_{p e}(i, j, c, n)$.

Similarly we calculate GWP by multiplying production by GWD intensity. We use food production data as three-year averages around 2000 and $2010,{ }^{16}$ corresponding to the commodities belonging to the 26 crop classes represented in the groundwater estimates (see list in ref. ${ }^{27}$ ).

We find that a smaller share of GWD associated with food production is traded, relative to the share of food production being traded, which can be explained by two phenomena. First, crops with relatively smaller GWD intensity may be more traded than others, or countries with relatively less GWD may be exporting more than other countries. The former is true for soybean, which is much more traded (61\% of production) than more GWD-intense rice (6\%); 
however, GWD-intense wheat is slightly more traded (25\%) than average. The latter is directly illustrated with India, the country with most GWD, which only exports 7\% of its cereal production, while France, with little GWD, exports $47 \%$ of its cereal production. ${ }^{16}$ However, other countries with significant GWD are large food exporters, such as the USA ( $22 \%$ of cereal production exported $\left.^{16}\right)$.

Code Availability The global hydrological model PCR-GLOBWB is an open source model that can be obtained from Utrecht University at http://www.globalhydrology.nl/models/pcrglobwb-2-0/. The algorithm for processing trade data is detailed in (11), the corresponding code is available upon request (from TK). Similarly, the calculation of GWC and GWT is detailed in this section and the code is available upon request from $\mathrm{CD}$.

Data The data sources for groundwater abstraction per crop are listed above. Food production, food trade, population, and national harvested area statistics are available in the FAOSTAT database: http : //faostat.fao.org. The conversion factors from raw crop to processed crop commodities are attached in SI Spreadsheet 2. 


\section{Extended Data Legends}

Figure 1: Embedded groundwater depletion in international trade of crop commodities in 2000. Volumes in $\mathrm{km}^{3} / \mathrm{y}$. The top ten importers are shown in bold font and the top ten exporters are underlined. Ribbons' colors indicate the country of export. Note that, for clarity, we only display the links with a weight of at least $1 \%$ that of the largest link (i.e. the top $1.8 \%$ links which account for $81 \%$ of total flow and involve 72 countries).

Figure 2: GWD embedded in crop exports, per capita of the exporting nation $\left(\mathrm{m}^{3} / \mathrm{cap} / \mathrm{y}\right)$ in 2010. The top ten exporters are underlined. Note that, for clarity, we only display the links with a weight of at least $1 \%$ that of the largest link (i.e. the top $3.2 \%$ links which account for $79 \%$ of total flow). 
Figure 3: GWD embedded in crop imports, per capita of the importing nation $\left(\mathrm{m}^{3} / \mathrm{cap} / \mathrm{y}\right)$ in 2010. The top ten importers are shown in bold font. Note that, for clarity, we only display the links with a weight of at least $1 \%$ that of the largest link (i.e. the top $1.6 \%$ links which account for $76 \%$ of total flow).

Figure 4: Exceedance probability distribution of national GWD (a,b) exports $\left(s_{\text {out }}\right)$ and (b,c) imports $\left(s_{i n}\right)$ in two versions of trade data ( $i e$ :import-export and $e i$ : export-import), for years (b,d) 2000 and (a,c) 2010.

Table 1: List of 130 primary crops used to aggregate trade flows of the 360 crop commodities considered, which are processed from these primary crops.

Table 2: List of crops in the GWD data - from MIRCA crop classes- excluded from the trade analysis. Trade volumes of the excluded fodder crops and grasses are negligible relative to other crops included in our trade analysis. Sugar beet and sugar cane are included as a generic sugar crop related to the primary crop "sugar raw centrifugal".

Table 3: Groundwater depletion exported (imported) and used by 10 countries with most depletion exports (imports), and top partner importing from (exporting to) them in 2010 and 2000. Groundwater depletion in national food production (GWP) and exports or imports (GWT). Difference of GWT with ei (export-import) trade dataset in absolute (Var $\left(\mathrm{km}^{3}\right)$ ) and relative $(\operatorname{Var}(\%))$ terms.

Table 4: Ten largest exporters of GWD per capita of exporting nation in 2010. GWE is the exported GWD in meters cube per capita.

Table 5: Ten largest importers of GWD per capita of importing nation in 2010. GWI is the imported GWD in meters cube per capita.

Table 6: Share of the world population importing at least $90 \%$ or $80 \%$ of a certain crop class from countries that have GWD associated with the production of these crops in years 2000 and 2010, for the ten most important crop classes in regards to this indicator. 